\title{
Rancangan Tata Letak Fasilitas Produksi Produk Rehabilitasi dengan Algoritma Genetika
}

\author{
Studi Kasus PT Shima Prima Utama
}

\author{
Steaven Leonardo Chandra \\ Jurusan Teknik Industri \\ Fakultas Sains dan Teknologi \\ Universitas Katolik Musi Charitas \\ steavenleonardo98@gmail.com \\ Theresia Sunarni \\ Jurusan Teknik Industri \\ Fakultas Sains dan Teknologi \\ Universitas Katolik Musi Charitas \\ t_sunarni@ukmc.ac.id
}

\author{
Kristoforus Jawa Bendi \\ Jurusan Teknik Informatika \\ Fakultas Sains dan Teknologi \\ Universitas Katolik Musi Charitas \\ kristojb@ukmc.ac.id \\ Dominikus Budiarto \\ Jurusan Teknik Industri \\ Fakultas Sains dan Teknologi \\ Universitas Katolik Musi Charitas \\ d_budiarto@ukmc.ac.id
}

\begin{abstract}
Abstrak - Tata letak fasilitas produksi memiliki dampak yang sangat penting dan saling keterkaitan antara fasilitas yang satu dengan lainnya guna menunjang kelancaran dari proses produksi. Seringkali masalah terbesar dalam sistem produksi disebabkan oleh penanganan bahan yang tidak sistematis. Dalam penelitian ini, kami mencoba menerapkan algoritma genetika dalam mendapatkan rancangan tata letak fasilitas (mesin) secara optimal. Input dari penelitian ini diantaranya berupa nomor mesin, masing-masing dimensi mesin, urutan mesin di setiap bagian, volume produksi di masing-masing bagian, dan frekuensi aliran di setiap bagian. Output dari penelitian ini adalah tata letak mesin dengan total biaya aliran minimum. Penelitian ini memecahkan kasus pada fasilitas produksi produk rehab di PT Shima Prima Utama yang terdiri dari 16 mesin dan 29 komponen. Hasil penelitian pada kasus ini adalah didapatkan urutan penempatan mesin optimal yakni $13,3,9,15,6,10$, $2,12,8,16,7,1,11,5,14$ dan 4 dengan total biaya aliran 197.434.
\end{abstract}

Kata kunci - tata letak fasilitas, algoritma genetika, ongkos perpindahan material, pendekatan heuristik.

\section{PENDAHULUAN}

\subsection{Latar Belakang}

Perancangan tata letak fasilitas mempertimbangkan masukan-masukan yang tepat dalam perubahan susunan fasilitas yang mungkin, jarak dan waktu perpindahan bahan, waktu tunggu, kemampuan mesin, jumlah mesin yang dibutuhkan, dan keluarankeluaran yang diinginkan. Aliran bahan merupakan inti dari proses produksi yang ekonomis. Dengan kata lain, perancangan tata letak fasilitas yang baik dapat mengefisienkan jarak dan ongkos perpindahan material. Perancangan tata letak fasilitas ini akan dilakukan di lantai produksi produk rehabilitasi PT Shima Prima Utama. Perancangan tersebut perlu dilakukan karena rancangan tata letak pada PT Shima Prima Utama yang ada saat ini tidak mempertimbangkan hubungan kedekatan fasiitas satu dengan fasilitas lainnya. terdapat aliran proses produksi yang bolak balik di lantai produksi produk rehabilitasi PT Shima Prima Utama sehingga mengakibatkan perpindahan material dengan jarak tempuh yang cukup jauh. Hal ini menyebabkan ongkos perpindahan material menjadi lebih tinggi.

Permasalahan tata letak lantai produksi produk rehabilitasi PT Shima Prima Utama dapat diselesaikan dengan menggunakan Algoritma Genetika. Penelitian yang telah dilakukan sebelumnya oleh Sahdar Rajak [8] yang melakukan penelitian untuk mengatasi permasalahan keterlambatan dalam proses produksi dikarenakan jarak perpindahan bahan pada proses produksi yang tinggi. Penelitian selanjutnya dilakukan oleh Nur Ulfaida Nasmar [6] dengan mengaplikasikan algoritma genetika untuk penyelesaian concentration location problem. Selain itu Hari Purnomo dan Kusumadewi [7] juga melakukan penelitian mengenai algoritma genetika untuk menentukan tata letak mesin guna mendapatkan total flow cost yang minimum. Maricar G. Misola dan Bryan B. Navarro [5] mengajukan penelitian serupa dengan menggunakan algoritma genetika dalam mendapatkan rancangan tata letak fasilitas yang optimal. Pada PT Shima Prima Utama sendiri telah dilakukan sebelumnya dengan menggunakan algoritma genetika oleh Ernawati [3] untuk menentukan rancangan tata letak usulan pada bagian 
welding hospital sedangkan penelitian ini dilakukan pada area produksi produk rehabilitasi. Pendekatan algoritma genetika pada penelitian ini terdiri dari enam tahapan diantaranya pembentukan populasi, seleksi individu induk, persilangan (crossover), mutasi, elitisme dan perulangan. Pemilihan pendekatan ini dilakukan dikarenakan fasilitasfasilitas yang ada di produk rehabilitasi cukup banyak dan produk yang diproduksi bervariasi sehingga pendekatan algoritma genetika tepat untuk permasalahan pada tata letak fasilitas lantai produksi produk rehabilitasi PT Shima Prima Utama. Hasil penelitian mengetahui posisi baru dalam tata letak fasilitas pabrik yang baik dan benar guna mengoptimalkan jalur proses produksi dan mengurangi proses jarak perpindahan bahan (material handling).

\subsection{Tinjauan Pustaka}

\subsubsection{Perancangan Tata Letak Pabrik}

Menurut Aqil [1] tata letak adalah suatu landasan utama dalam dunia industri. Tata letak pabrik atau tata letak fasilitas dapat didefinisikan sebagai tata cara pengaturan fasilitas-fasilitas pabrik guna menunjang kelancaran proses produksi. Tujuan perencanaan dan pengaturan tata letak pabrik adalah untuk menaikkan output produksi, mengurangi waktu tunggu (delay), mengurangi proses perpindahan bahan (material handling), penghematan penggunaan area untuk produksi, gudang, dan service, pendaya guna yang lebih besar dari pemakaian mesin, tenaga kerja, dan fasilitas produksi lainnya; mengurangi inventory in-process; proses manufaktur lebih singkat; mangurangi resiko bagi kesehatan dan keselamatan kerja dari operator; memperbaiki moral dan kepuasan kerja; mempermudah aktivitas supervisi mengurangi kemacetan dan kesimpang-siuran; dan mengurangi faktor yang bisa merugikan dan memperngaruhi kualitas dari bahan baku ataupun produk jadi.

\subsubsection{Perpindahan Material}

Pengertian perpindahan material berdasarkan adalah seni dan ilmu yang meliputi penanganan (handling), perpindahan (moving), pembungkusan (packing), penyimpanan (storing), sekaligus pengendalian dan pengawasan (controlling) dari bahan atau material dengan segala bentuknya [9]. Faktor-faktor yang dipertimbangkan dalam perhitungan perpindahan material antara lain jarak angkut, frekuensi angkut dan biaya angkut. Jarak angkut berdasarkan rectilinear didapatkan dengan rumus sebagai berikut.

$\operatorname{dij}=|(x i-x j)+(y i+y j)|$

\subsubsection{Konsep Dasar Algoritma Genetika}

Menurut Purnomo [7], Algoritma genetika adalah algoritma pencarian heuristik yang didasarkan atas mekanisme evolusi biologis. Keberagaman pada evolusi biologis adalah variasi dari kromosom antar individu organisme. Variasi kromosom ini akan mempengaruhi laju reproduksi dan tingkat kemampuan organisme untuk tetap hidup. Secara sederhana algoritma genetika terdiri-dari langkahlangkah sebagai berikut.

1. Generasi $=0$ (generasi awal).

2. Inisialisasi populasi awal, $\mathrm{P}$ (generasi), secara acak.

3. Evaluasi nilai fitness pada setiap individu dalam $\mathrm{P}($ generasi).

4. Kerjakan langkah-langkah berikut hingga generasi mencapai maksimum generasi:

a) Generasi $=$ generasi +1 (tambah generasi).

b) Seleksi populasi tersebut untuk mendapatkan kandidat induk, P'(generasi).

c) Lakukan crossover pada P'(generasi).

d) Lakukan mutasi pada P'(generasi); mutasi ini bersifat optional.

e) Lakukan evaluasi fitness setiap individu pada P'(generasi).

f) Bentuk populasi baru: $\mathrm{P}($ generasi $)=$ $\{\mathrm{P}($ generasi-1) yang survive, $\mathrm{P}$ '(generasi) $\}$

1.2.4 Menentukan Populasi Awal dan Nilai Fitness

Populasi awal pada algoritma genetika adalah sekumpulan individu yang dipilih dengan dua cara yaitu dengan memilih individu secara aak, atau dengan membimbing populasi awal ke suatu keadaan yang lebih mengarah ke pemecahan masalah [2].

\subsubsection{Seleksi Individu Induk}

Seleksi ini bertujuan untuk memberikan kesempatan reproduksi yang lebih besar bagi anggota populasi yang memiliki fitness tinggi untuk melakukan reproduksi. Metode seleksi yang digunakan adalah metode roda roulette. Algoritma seleksi dengan roda roulette dapat dilihat pada penjelasan berikut ini [7].

\section{Hitung total fitness $(\mathrm{F})$ :}

TotFitness $=\Sigma \mathrm{Fk} ; \mathrm{k}=1,2, \ldots$,popsize.

2. Hitung fitness relatif tiap individu:

$\mathrm{pk}=\mathrm{Fk} /$ TotFitness

3. Hitung fitness komulatif:

$\mathrm{q} 1=\mathrm{p} 1$

$\mathrm{qk}=\mathrm{qk}-1+\mathrm{pk} ; \mathrm{k}=2,3, \ldots$, popsize

4. Pilih induk yang akan menjadi kandidat untuk dicrossover dengan cara:

Bangkitkan bilangan random $r$.

Jika $\mathrm{qk} \leq \mathrm{r}$ dan $\mathrm{qk}+1>\mathrm{r}$, maka pilih kromosom ke $(\mathrm{k}+1)$ sebagai kandidat induk. 


\subsubsection{Pindah Silang (Crossover)}

Crossover (pindah silang) dilakukan atas 2 kromosom untuk menghasilkan kromosom anak (offspring). Kromosom anak yang terbentuk akan mewarisi sebagian sifat kromosom induknya. Metode crossover yang akan digunakan untuk kasus ini adalah metode Partial-Mapped Crossover atau PMX [4].

Berikut contoh melakukan persilangan (crossover) menggunakan metode PMX.

1. Pilih posisi untuk menentukan substring secara acak

Induk 1: $12|3456| 789$

Induk $2: 54|6921| 783$

2. Tukar substring diantara induk

Protochild 1:12|6921|789

Protochild 2:54|3456|783

3. Menentukan hubungan mapping

$\left|\begin{array}{llll}6 & 9 & 2 & 1\end{array}\right|$

Hasil mapping

$1-6-3$

$2-5$

$9-4$

4. Menentukan kromosom keturunan mengacu pada hubungan mapping

Offspring $1: 35|6921| 784$

Offspring $2: 29|3456| 781$

\subsubsection{Mutasi}

Mutasi mencegah kehilangan total materi genetika setelah reproduksi dan pindah silang. Mutasi ini berperan utuk menggantikan gen yang hilang dari populasi akibat seleksi yang memungkinkan munculnya kembali gen yang tidak muncul pada inisialisasi populasi [5]. Teknik mutasi yang digunakan adalah swap mutation. Ilustrasi berikut ini menunjukkan contoh penggunaan swap mutation.

- Sebelum mutasi

Offspring : 538167429

- Setelah mutasi

Offspring : 578163429

\subsubsection{Elitisme}

Proses seleksi dilakukan secara random sehingga tidak ada jaminan bahwa suatu individu yang bernnilai fitness tertinggi akan selalu dipilih. Walaupun individu bernilai fitness tertinggi dipilih, mungkin saja individu tersebut akan rusak karena proses pindah silang. Oleh karena itu, untuk menjaga agar individu berniai fitness tertinggi tersebut tidak hilang selama evolusi, maka perlu dibuat satu atau beberapa kopinya, prosedur ini dikenal sebagai elitisme [3].

\subsubsection{Perulangan}

Tahapan diatas, yaitu: seleksi orang tua, penyilangan, mutasi, dan elitisme dilakukan berulang sehingga ditemukannya kondisi terminasi. Kondisi terminasi yang dimaksud adalah berhenti pada generasi tertentu, yaitu saat populasi awal diubah menjadi populasi baru sebanyak jumlah generasi, berhenti setelah dalam beberapa generasi berturut-turut didapatkan nilai fitness tertinggi tidak berubah, berhenti bila dalam $n$ generasi berikut tidak didapat nilai fitness yang lebih tinggi [8].

\subsection{Metodologi Penelitian}

Kerangka konsep penelitian kuantitatif [10] dijabarkan sebagai berikut:

a. Input

Input yang digunakan berupa layout lokasi produksi produk rehab, jumlah mesin, dimensi mesin (panjang, lebar), frekuensi aliran material, jenis komponen dan mesin yang digunakan setiap komponen. Pengumpulan data dilakukan dengan melakukan wawancara dan observasi secara langsung.

\section{b. Proses}

1. Mencari nilai fitness untuk digunakan pada tahap berikutnya dengan menggunakan seleksi roda roulette.

2. Menghasilkan kromosom baru dari proses 2 kromosom dengan metode crossover PMX.

3. Mutasi dilakukan dengan menggunakan swap mutation.

4. Melestarikan nilai terbaik dan mengulangi proses sebanyak 10 generasi.

\section{c. Output}

Output yang didapatkan berupa urutan susunan mesin dan jarak perpindahan bahan secara optimal dari hasil tata letak fasilitas yang dinginkan secara baik.

\section{PEMBAHASAN}

\subsection{Data Penelitian}

Pengumpulan data dilakukan dengan cara wawancara dan observasi langsung ke PT Shima Prima Utama. Data yang diperoleh adalah data tata letak awal lantai produksi, data produk/komponen yang diproduksi, urutan proses, jumlah produksi, mesin yang digunakan, jumlah mesin, dan data ukuran mesin/fasilitas. Penelitian membahas produk rehabilitasi berupa kursi roda. Tata letak lantai produksi PT Shima Prima Utama ditunjukkan pada Gambar 1. 


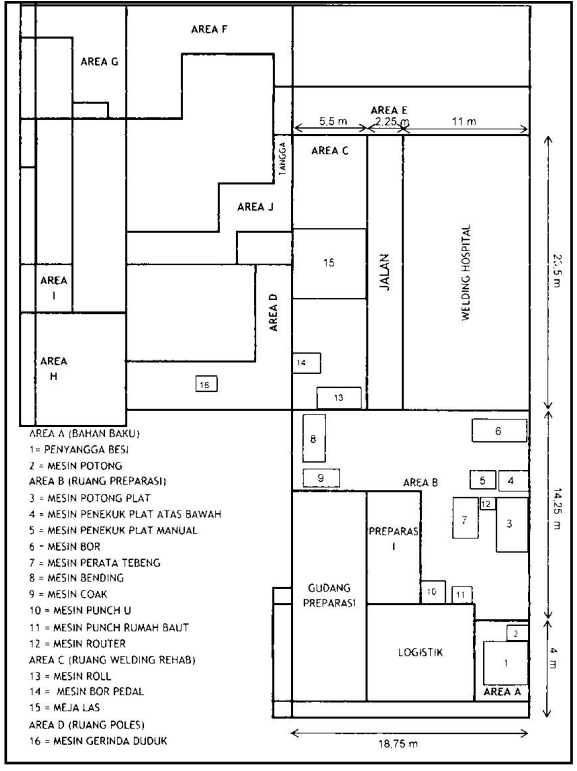

Gambar 1. Tata Letak Awal Lantai Produksi PT Shima Prima Utama

Selanjutnya pada Tabel 1 menunjukkan data ukuran mesin atau fasilitas, Tabel 2 data urutan proses produksi serta jumlah produksi kursi roda selama 1 tahun pada PT Shima Prima Utama.

TABEL 1. Data Ukuran Mesin / Fasilitas Untuk Frame Kursi Roda

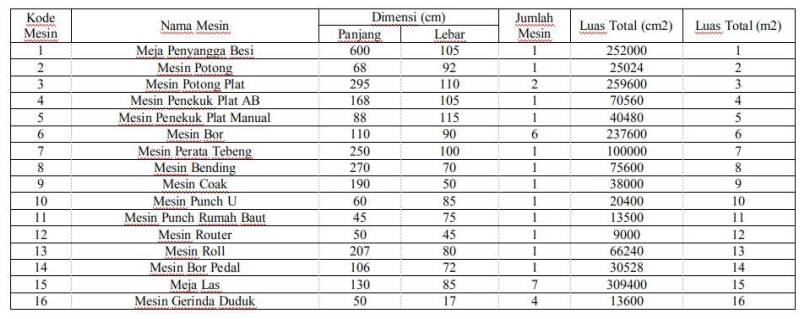

TABEL 2. Tata Urutan Proses Produksi dan Jumlah Produksi Produk Kursi Roda

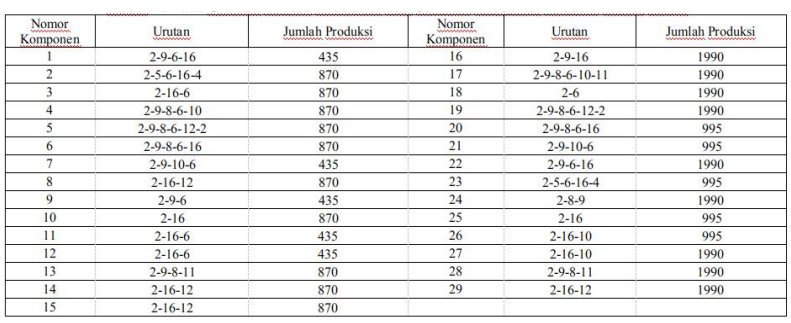

\subsection{Penentuan Frekuensi dan Jarak Perpindahan}

Frekuensi perpindahan material antar mesin diperoleh dari total volume dibagi kapasitas sekali angkut. Pada PT Shima Prima Utama, kapasitas angkut sebesar 100 unit. Frekuensi perpindahan ditunjukkan pada Tabel 3 dan Jarak perpindahan pada Tabel 4.
TABEL 3. Frekuensi Perpindahan Material

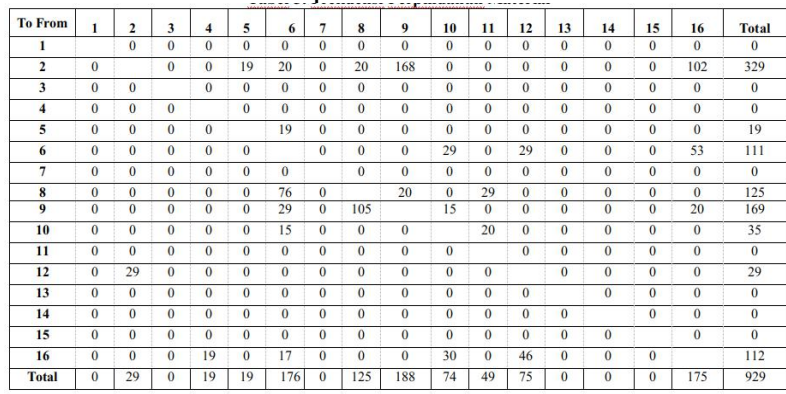

TABEL 4. Jarak Perpindahan Part Pada Mesin atau Fasilitas

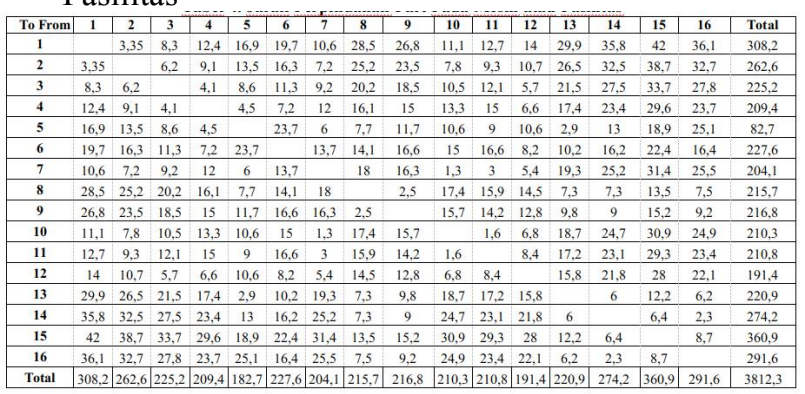

Nilai fitness didapatkan dengan menjumlahkan perkalian antara jarak, frekuensi dan biaya perpindahan material. Diasumsikan biaya untuk perpindahan material per $1 \mathrm{~m}$ adalah 5 detik sehingga biaya perpindahan material per meter $\operatorname{Rp} 23,-$

TABEL 5. Nilai Fitness Layout Awal

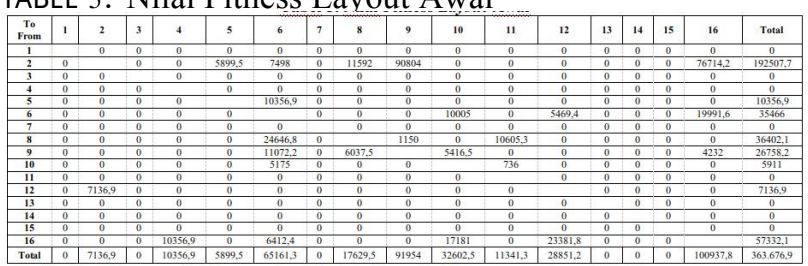

Dari hasil perhitungan nilai fitness maka didapatkan fitness dari layout awal sebesar 363.677.

\subsection{Perancangan Tata Letak dengan Algoritma Genetika}

Tahapan yang dilakukan dalam perancangan tata letak dengan algoritma genetika adalah:

1. Menentukan populasi awal

Populasi awal ditentukan secara random dengan membangkitkan angka random sejumlah jumlah mesin yang ada yakni sebanyak 16 buah. Jumlah individu yang dibangkitkan adalah sejumlah 10 buah individu.

TABEL 6. Populasi Awal Dengan Bilangan Random

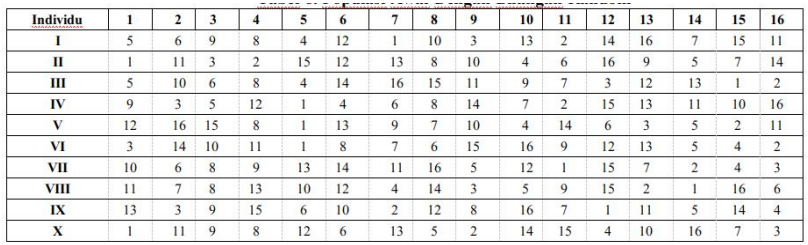


TABel 7. Biaya Perpindahan Material Pada Populasi Awal

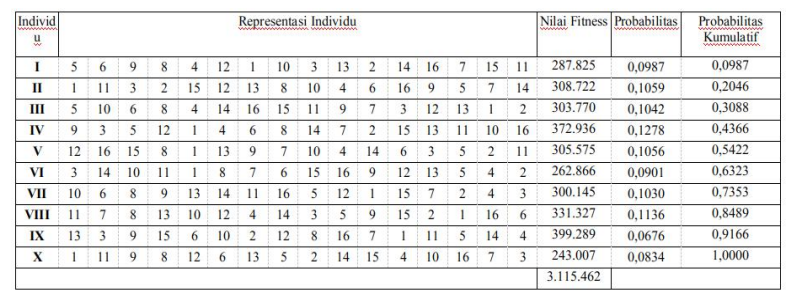

\section{Seleksi Individu Induk (Parental)}

Penyeleksian individu dilakukan dengan membangkitkan 2 bilangan random untuk memilih individu induk (parental). Penyeleksian dilakukan dengan menggunakan metode roulette wheel. Dari hasil pembangkitan bilangan parental yang terpilih adalah 0,268 dan 0,610 sehingga parental yang terpilih adalah individu III dan individu VI.

Individu III $\quad: \begin{array}{llllllllllllllll}5 & 10 & 6 & 8 & 4 & 14 & 16 & 15 & 11 & 9 & 7 & 3 & 12 & 13 & 1 & 2\end{array}$

Individu VI $: 31410111807 \quad 6 \quad 1516 \quad 91213 \quad 5 \quad 4 \quad 2$

\section{Persilangan (Crossover)}

Persilangan dilakukan dengan metode partial mapped cross over (PMX) dengan menggunakan bantuan dari bilangan random. Bilangan random diacak sejumlah fasilitas yang ada yakni 16 buah sebanyak dua kali yang bertujuan untuk menentukan 2 buah substring. Pada persilangan kali ini, bilangan random yang muncul adalah bilangan random 5 dan 12, yang menjadi substring pada persilangan berikut ini.

Individu III: $5 \begin{array}{llllllllllllllll}10 & 6 & 8 & 4 & 14 & 16 & 15 & 11 & 9 & 7 & 3 & 12 & 13 & 1 & 2\end{array}$

Individu VI : $3 \quad 14$\begin{tabular}{lll|lllllll|llll}
10 & $11 \mid$ & 1 & 8 & 7 & 6 & 15 & 16 & 9 & 12 & 13 & 5 & 4 & 2
\end{tabular}

Setelah posisi substring ditentukan, maka dilakukan pertukaran substring diantara kedua induk menjadi seperti berikut ini.

Individu III: 5 \begin{tabular}{llllllllllll|llll}
10 & 6 & 8 & 4 & 8 & 7 & 6 & 15 & 16 & 9 & 12 & 12 & 13 & 1 & 2
\end{tabular}

Individu VI : $314 \quad 1011 \mid$\begin{tabular}{llllllll|llll}
1 & 14 & 16 & 15 & 11 & 9 & 7 & $3 \mid$ & 13 & 5 & 4 & 2
\end{tabular}

Karena, terdapat jenis mesin yang kembar dalam satu individu, maka dilakukan penentuan hubungan dengan cara pemetaan (mapping) seperti berikut ini.

Individu III : $8 \quad 7 \quad 6 \quad 61516 \quad 912$

Individu VI : 14161511973

Hubungan pemetaan : 8-14, 7-16-9, 6-15-11, 12-3

Sehingga didapatkan kromosom keturunan yang mengacu pada hubungan mapping seperti berikut ini.

Individu III $\quad: \begin{array}{llllllllllllllll}5 & 10 & 11 & 14 & 4 & 8 & 7 & 6 & 15 & 16 & 9 & 12 & 3 & 13 & 1 & 2\end{array}$

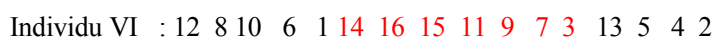

\section{Mutasi (Mutation)}

Mutasi dilakukan dengan metode swap mutation dengan menggunakan dua buah bilangan random untuk setiap individu anak dalam menentukan jenis mesin yang ditukarkan. Bilangan random yang dipilih untuk dilakukan mutasi adalah pada individu III yaitu 5 dan 14. Pada individu VI yaitu 2 dan 7.

Individu III $\quad: 5 \quad 1011 \quad 14 \quad 4 \quad 8 \quad 7 \quad 6 \quad 1516 \quad 912 \quad 3 \quad 13 \quad 12$

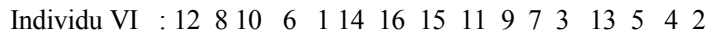

Setelah dilakukan mutasi maka didapatkan hasil seperti berikut ini.

Individu II $\quad: \begin{array}{lllllllllllllll}5 & 10 & 11 & 14 & 13 & 8 & 7 & 6 & 15 & 16 & 9 & 12 & 3 & 4 & 1\end{array}$

$\begin{array}{lllllllllllllllll}\text { Individu VI } & : & 12 & 16 & 10 & 6 & 1 & 14 & 8 & 15 & 11 & 9 & 7 & 3 & 13 & 5 & 4\end{array}$

Penentuan nilai fitness dari individu III dan individu VI setelah dilakukannya persilangan dan mutasi adalah individu III sebesar 271.837 dan individu VI sebesar 324.351. Karena individu yang memiliki nilai fitness lebih kecil adalah individu III, maka pada perulangan 1 individu III adalah individu terpilih.

\section{Perulangan}

Perulangan dilakukan terus menerus sampai didapatkan individu anak yang lebih baik. Perulangan yang dilakukan pada saat ini adalah dengan melakukan perulangan sebanyak 10 kali. Setelah direkapitulasi keseluruhan individu terpilih dari masing- masing perulangan (elitisme), maka hasil rekapitulasi dapat dilihat pada tabel 8 dibawah ini.

TABEL 8. Rekapitulasi Nilai Fitness Terbaik Keseluruhan Perulangan

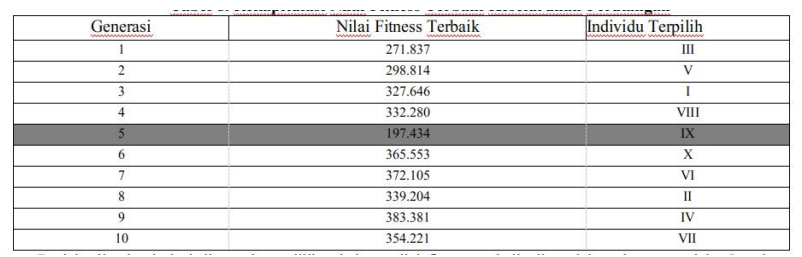

Dari hasil rekapitulasi diatas dapat dilihat bahwa nilai fitness terbaik diperoleh pada generasi ke-5 pada individu ke-9 yakni sebesar 197.434. Maka dari itu pengaturan tata letak usulan akan mengikuti urutan kromosom dari individu ke-9 pada generasi ke-5.

\section{Tata Letak Usulan Lantai Produksi PT Shima Prima Utama}

Tata letak lantai produksi PT Shima Prima Utama ditunjukkan pada gambar 2 berikut ini. 


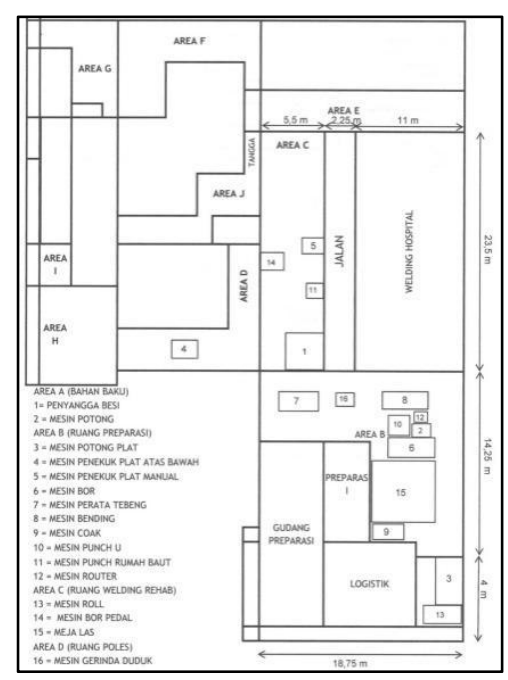

Gambar 2. Tata Letak Usulan Lantai Produksi PT Shima Prima Utama

\section{KESIMPULAN}

Berdasarkan hasil perancangan tata letak yang telah dilakukan maka diperoleh simpulan yakni total biaya perpindahan material mengalami penurunan, yaitu sebesar Rp 166.243 per bulan atau 45,71\%. Penurunan total perpindahan material tersebut didapat dari total biaya perpindahan pada tata letak awal yaitu sebesar Rp 363.677 per bulan dan Rp197.434 per bulan pada tata letak usulan. Dengan penurunan biaya perpindahan material tersebut dapat pula disimpulkan bahwa rancangan tata letak usulan tersebut dapat diterapkan pada PT Shima Prima Utama.

\section{Ucapan Terima Kasih}

Tulisan ini merupakan bagian dari penelitian terapan yang dibiayai oleh DRPM, Dirjen Penguatan dan Pengembangan, Kemenristekdikti dengan Nomor Kontrak 19/II/BI-PN1009/4/19. Terima kasih kami ucapkan kepada Kemenristekdikti atas hibah penelitian ini, kepada para kolega Universitas Katolik Musi Charitas, dan mahasiswa peserta mata kuliah Perancangan Tata Letak dan Fasilitas.

\section{DAFTAR PUSTAKA}

[1] Aqil, Abdul Wahab. 2010. Perancangan Tata Letak Fasilitas Menggunakan Blocplan : Studi Kasus Industri Kecil Tahu Sumber Rejeki Sukoharjo. Surakarta : Universitas Muhammadyah Surakarta.

[2] Carwoto. 2007. Implementasi Algoritma Genetika untuk Optimasi Penempatan
Kapasitor Shunt pada Penyulang Distribusi Tenaga Listrik. Makalah disajikan dalam Jurnal Teknologi Informasi DINAMIK Volume XII, STMIK ProVisi Semarang, Semarang, 2 Juli.

[3] Ernawati. 2008. Usulan Perbaikan Tata Letak Fasilitas Welding Furniture Dengan Pendekatan Genetic Algorithm : Studi Kasus Pada PT Shima Prima Utama. Palembang : Sekolah Tinggi Teknik Musi.

[4] Melvani, Sri Hardi. 2014. Analisis Mapping Pada Partially Mapped Cross Over Dalam Algoritma Genetika Pada Travelling Salesman Problem. Makalah disajikan dalam TECHSI Vol 4. Nomor 1 2014, Universitas Sumatera Utara, Medan, 1 April.

[5] Misola, Maricar G.. 2013. Optimal Facility Layout Problem Solution Using Genetic Algorithm. Makalah disajikan dalam Engineering and Technology International Journal of Industrial and Manufacturing Engineering Vol:7, No:8, 2013.

[6] Nasmar, Nur Ulfaida. 2016. Aplikasi Optimalisasi Tata Letak Dengan Menggunakan Algoritma Genetika Untuk Penyelesaikan Concentration Location Problem. Makassar : UIN Alauddin Makassar.

[7] Purnomo, Hari. 2005. Aplikasi Algoritma Genetika Untuk Penentuan Tata Letak Mesin. Yogyakarta : Universitas Islam Indonesia.

[8] Rajak, Sahdar. 2018. Optimasi Tata Letak Fasilitas Produksi Menggunakan Algoritma Genetika. Yogyakarta : Universitas Islam Indonesia.

[9] Wignjosoebroto, Sritomo. 2009, Tata Letak Pabrik dan Pemindahan Bahan. Surabaya : Guna Widya

[10] Dwipriyoko, E., Bon, A. T. B., \& Sukono, F. (2019), Enterprise Architecture Planning as New Generation Cooperatives Research Methods, Journal of Physics: Conference Series (Vol. 1179, No. 1, p. 012094), IOP Publishing. 